\title{
Development of A "Product Design" Guidelines Book Based on Indonesia National Curriculum Framework (KKNI) to Develop Creative Industries Students of Education Department of Family Welfare State University of Medan
}

\author{
Fatma Tresno Ingtyas*, Nuwairi Hilda, Nila Handayani \\ \{*fyingtyas@gmail.com\} \\ Universitas Negeri Medan, Medan, Indonesia
}

\begin{abstract}
Product Design is a new subject that is compulsory in the Department of Family Welfare Education, so that all of these courses must be in the Fashion Design Education Study Program, Catering Education, Cosmetology and Nutrition Education. The discussion of a quality learning process in accordance with the curriculum is conducted intensively, but the reality in the field shows that there are not many lecturers who want to practice when conducting lectures. Students view the material as too theoretical, giving no contextual examples. Creative learning has a strategic position in developing student competencies, both technical competence (hard competence) and entrepreneurial skills (soft-competence). This study aims to develop a product design learning tool to enhance the creative industry, including, Product Design Guidebook, Semester Program Design, teaching materials, learning methods, and evaluation of learning outcomes, which can develop creative industries. Learning material needs to be designed by focusing on joint exhibition activities (creating or creating products both goods and services in accordance with the study program) that emphasize character, assignment or project-work learning methods, and evaluation of learning outcomes need to apply performance evaluation techniques by emphasizing evaluation processes and products. This research is a development research, with the instruments used are questionnaires and interviews. Data were analyzed using qualitative descriptive analysis techniques and quantitative descriptive statistical analysis. The results of this study is, that the existence of a product design guide book on the family welfare education department that is validated and suitable for student use. It is expected that there will be a Product Design Guidebook to improve the creative industry which is measured from the effectiveness of the experts and validators of learning design, so that the character of the student creative industry.
\end{abstract}

Keywords: Development of learning tools, product design, creative industry

\section{Introduction}

In the process of implementing learning in the Family Welfare Education Department, it is known that innovation and creative learning. This learning contains a set of courses that specifically aim to equip students to have productive competencies through the learning of 
Product Design, in accordance with the Indonesian National Qualification Curriculum. The strategic position of learning to improve the creative industry is basically a benchmark that should be a reference for quality in the implementation of the Family Welfare Education Department. However, in reality it has not been used optimally, especially for the development of the character and entrepreneurial spirit in developing the creative industries that the government is currently proclaiming. Creating a design that solves problems certainly requires a brilliant idea so that the problem is solved and finds a creative concept. The process of finding the idea requires a joint discussion phase with each other randomly devoting ideas and opinions called brainstorming. This process is very important because this is where ideas become increasingly explored from various perspectives. In the design method, there are two methods of designing products namely creative methods and rational methods. The design method aims to help stimulate creative thinking by increasing the production of ideas, removing mental barriers to creativity or by expanding the solution search area. While the rational method emphasizes a systematic approach to design.

Learning from the large number of graduate graduates who are not absorbed in employment, if linked to limited employment, while the number of graduates is increasing sharply every year, the development of an entrepreneurial mental attitude has strategic value. This is because the development of character and entrepreneurial spirit means that the organization in the Family Welfare Education Department is not only focused on preparing graduates to become business/ industrial world workers, but also focusing on the formation of entrepreneurial character to improve the creative industry. The need for the development of entrepreneurial character is actually in line with the results of research at Harvard University in the United States, which states that one's success is not determined solely by knowledge and technical skills (hard skills), but rather by the ability to manage themselves and others (softskill). This study reveals, a person's success is only determined around $20 \%$ by hard skills and the remaining $80 \%$ by soft skills (Ministry of National Education, 2010).

Developing a Product Design course is a course in the Department of Family Welfare Education in the IQF curriculum, especially requiring the right approach in developing creative industries, both classrooms learning and practice. Actually, the development of teaching materials, learning methods, and learning outcomes assessment system in this Product Design course focuses on referring to character indicators on creative learning which basically can develop and shape the competencies and characters of students of the Family Welfare Education Department.

Inter-sectorial collaboration between product design and various related sciences (engineering, humanities, science, business and management) is the main prerequisite for equipping reliable product design experts. For this reason learning in product design courses must anticipate this challenge by producing graduates / graduates who: Have the knowledge, skills and knowledge about designing creative industrial products that are in line with the latest information about the household industry; Having high creative power in solving design and innovation problems, through mastering the basic principles of technology, science and visual elements; Able to carry out product research and development through various multidisciplinary methods and approaches and cooperate well in a design team; Able to conduct reviews and analysis through various aspects (technology, humanities, social, and culture) on the development of industrial product design both nationally and internationally; Having the ability to present and communicate ideas, processes, design results, and evaluations in a clear, systematic and effective manner.

Designing the same as this design word seems not to be able to interpret the design more broadly, the word "Design" from the word design (English) is retained. A good design only on 
paper only falls just as a concept culture. Because however good design is a design that meets the needs of the community. Besides that the acceptance of the community to a design must be critical, because without these elements there is no healthy growth of design. With that understanding, it provides an illustration that design is not solely owned by one of the disciplines, but belongs to all disciplines, because basically design is a cross-field between art, science and technology. Based on the background description in the introduction, the formulation of the problem of this research is: How is the development of learning equipment for packaged Product Design to develop Creative Industries for Student Family Welfare Education Department?

Product design is a field of design expertise that studies and plans for disposable objects, which are manufactured industrially. The scope of the expertise is broad, ranging from simple items such as household appliances, furniture, props, and children's toys, to modern high-tech equipment such as equipment, transportation, household equipment. Product design emphasizes its main concern on the relationship between humans as users and products as objects of use. The emphasis is on reciprocal relationships that involve consideration that includes technical, functional, psychological and market aspects. The design of a product requires adequate insight into materials, production processes, human behavior and social, cultural and economic demands. A product besides being demanded not only has technical, economic or just physical needs, but is also expected to answer the demands of symbolic functions, beauty, comfort and beauty.

Product design consists of two words namely design and product according to the large Indonesian dictionary, design means the form or design framework. While the product means the goods or services that are made and added to the use or the value is then processed into the final production process. So the understanding of product design is one of the activities that design a form and then processed through the production process and the end result becomes a product that is produced from the production process and its value and usefulness can meet consumer desires that are adapted to changing times and times. Product design is a profession whose activities are related to a process of technological innovation. Product design is the process of creating new products sold by the company for its customers. A very broad concept, basically the generation and development of effective and efficient ideas through processes that lead to new products. In a systematic approach, product designers conceptualize and evaluate ideas, and turn them into real discoveries of products. The role of designer products is to combine art, science and technology to create new products that can be used by others

The term "Industrial Product Design" or "Industrial Design" first appeared in the early 20th century as a description of the creative preliminary process of mass-produced goods. To overcome the complexities of a mass production process, product designers need to carry out product usability tests to ensure that a product can meet the needs, desires, and expectations of its users, and often they rearrange its components or parts to make products more efficient to be manufactured and easy to assemble, repair and recycle.

\section{Methodology}

The design applied in this research is research and development [1]. This research was at the Department of Education for Family Welfare, with research subjects, namely the fields of food, clothing, makeup and nutrition. One skill competency is taken to develop learning tools 
namely Guidebook, Semester Learning Plan, teaching material, learning method, and evaluation system with reference to indicators based on the creative industry. Preliminary studies were carried out using questionnaire techniques and literature review, namely the distribution of questionnaires to students. At the development stage used Focus group discussion techniques, with data collection techniques Data collection instruments used in this study are: questionnaires used to collect data at the preliminary study and development stages; questionnaire (rating scale) is used to assess the results of the application of population design courses based on the creative industry.

The instruments used in this study were: questionnaire sheets for the needs of lecturers and students; questionnaire sheets for material experts; used to obtain data on the quality of product design materials and the development of learning delivery systems; questionnaire sheets for learning design experts; used to obtain data about the quality of learning and technical design of the product, Semester Learning Plan and joshed by learning design experts; observation sheet; which is used to obtain data about product design learning.

\section{Result and Discussion}

The process of developing a Learning Guidebook Product design is done in stages, which is done is to do a needs analysis and data collection. The activity was carried out to obtain data on the teaching and learning process, characteristics and learning needs of students, problems that existed in learning and developing guidebooks during the learning process. The needs analysis phase consists of an analysis of lecturer needs and an analysis of student needs.

The results of the questionnaire for lecturers' needs (99\%) stated that the Product Design Learning manual was not available, so that it needed the development of learning manuals in an effort to improve more effective and interesting learning. The results of the questionnaire for student needs $(48 \%)$ stated strongly agree and (52\%) agreed if there was a product design guidebook. Expert validation is carried out by competent experts, consisting of two lecturers who are experts in the field of learning media. Media experts validate products on aspects of book appearance, efficiency, and technical quality, program effectiveness.

Table 1. Score Assessment by Media Experts Display Aspects

\begin{tabular}{llcc}
\hline No & Indicator & Score $(\%)$ & Criteria \\
\hline 1 & Conformity with student character & 83 & Well \\
2 & Use of good and correct Indonesian & 99 & Good luck \\
3 & The language used is easily understood by students & 90 & Good luck \\
4 & withdrawal of guidebooks & 82,3 & Well \\
5 & suitability of the image & 80 & Well \\
6 & the attractiveness of the color of the book & 84 & Well \\
7 & Clarity of text in the book & 90,5 & Good luck \\
\hline & Average & 85,6 & Good luck \\
\hline
\end{tabular}

Based on the results of the media expert's validation, it was seen the display aspect of the Guidance namely suitability to student character (83\%), good and correct use of Indonesian $(99 \%)$, easy language understood by students (90\%), book design attractiveness $(82.3 \%)$, 
Suitability of the image (80\%), color composition (84\%), text clarity $(90.5 \%)$, overall average for the aspect of the guidebook display is $(85.6 \%)$.

Table 2. Scoring scores by Media Experts Aspects of Efficiency

\begin{tabular}{clcc}
\hline No & Indicator & Score $(\%)$ & Criteria \\
\hline 1 & Workbook guidelines & 92 & Very Good \\
2 & Ease of Use of the Guidebook & 92,5 & Very Good \\
\hline & Average & 92,25 & Very Good \\
\hline
\end{tabular}

Based on the results of expert validation in table 2, the efficiency aspects for the score manual workflow (92\%), ease of use of the guidebook $(92.5 \%)$ were seen. Overall the average score on the efficiency aspect $(92.25 \%)$.

Table 3. Scoring scores by Media Experts Aspects of Technical Quality, Effectiveness of the Guidebook

\begin{tabular}{llcc}
\hline No & Indicator & Score $(\%)$ & Criteria \\
\hline 1 & Clarity and accuracy of the contents of the book & 91 & Very Good \\
2 & Book Writing is not boring & 82 & Good \\
3 & Accuracy of evaluation & 90,3 & Very Good \\
5 & The marginalization of the Guidebook & 81,2 & Good \\
6 & Innovative presentation of material & 90 & Very Good \\
7 & The overall creativity of the Book & 89 & Very Good \\
\hline & Average & 86,3 & Good \\
\hline
\end{tabular}

The results of media expert validation showed aspects of technical quality, effectiveness, clarity and attractiveness of the guidebook (91\%), open display was not boring (82\%), accuracy of evaluation $(90.3 \%)$, manual guidebook $(81.2 \%)$ in criteria good, display of book content (89\%), and innovative presentation of material $(90 \%)$ Overall the average number of scores on aspects of technical quality, program effectiveness is $86.3 \%$ in very good criteria.

Table 4. Level of Trends in the Assessment of Media Experts on Aspects of Book Display

\begin{tabular}{lcccc}
\hline No & Criteria & Interval & Frequency & Precent \\
\hline 1 & Very Good & $85 \% \leq$ skor $\leq 100 \%$ & 5 & $27,78 \%$ \\
2 & Very & $69 \% \leq$ skor v $84 \%$ & 13 & $72,22 \%$ \\
3 & Pretty good & $53 \% \leq$ skor $\leq 68 \%$ & 0 & $0 \%$ \\
4 & Not good & $37 \% \leq$ skor $\leq 52 \%$ & 0 & $0 \%$ \\
5 & Not very good & $20 \% \leq$ skor $\leq 36 \%$ & 0 & $0 \%$ \\
\hline
\end{tabular}

Based on the observations of the results of media experts in table 4 , it can be seen from the manual guidelines for the level of tendency $(27.78 \%)$ and $(72.22 \%)$ good.

Table 5. Comments and Suggestions for Improvement from Media Experts

Media
Expert Comments and Suggestions




\begin{tabular}{|c|c|}
\hline $\begin{array}{l}\text { Media } \\
\text { Expert }\end{array}$ & Comments and Suggestions \\
\hline $\begin{array}{l}\text { Media } \\
\text { Expert } \\
\text { I }\end{array}$ & $\begin{array}{l}\text { Improved book cover design } \\
\text { Add a look to the design cover book of the study program } \\
\text { The color composition of the cover must be considered to be balanced } \\
\text { Add interesting pictures in the contents of the book }\end{array}$ \\
\hline $\begin{array}{l}\text { Media } \\
\text { Expert } \\
\text { II }\end{array}$ & $\begin{array}{l}\text { is already well used in learning Product Design } \\
\text { The content display is adjusted material and image so that the material } \\
\text { flow can be easily understood. } \\
\text { The text in the guidebook must also be adapted to the guidelines for } \\
\text { writing a good manual. }\end{array}$ \\
\hline
\end{tabular}

Validation of material experts on the development of the Product Design Guidebook carried out by material experts conducted for information was used to find out the shortcomings and feasibility of the material.

Table 6. Score Assessment by Material Experts on Educational Aspects

\begin{tabular}{|c|c|c|c|}
\hline No & Indicator & Score $(\%)$ & Crietria \\
\hline 1 & Compatibility of material with the curriculum & 98 & Very Good \\
\hline 2 & The accuracy of the material with the syllabus & 98 & Very Good \\
\hline 3 & $\begin{array}{l}\text { The accuracy of the material with the Semester } \\
\text { Learning Design }\end{array}$ & 99 & Very Good \\
\hline 4 & Compatibility of material with competence & 90 & Very Good \\
\hline \multirow[t]{2}{*}{5} & Conformity of the material with the aim of learning & 97 & Very Good \\
\hline & Average & 97 & Very Good \\
\hline
\end{tabular}

Based on the results of material expert validation on aspects of material accuracy, namely material integrity $(90 \%)$, material presentation flow $(91 \%)$, material determination with preliminary activities (98\%), material accuracy with core activities (92\%), material provisions with closing activities (91\%), appropriateness of evaluation with material (92\%). Overall the average aspect of material accuracy is $(96.7 \%)$.

Table 7. Evaluation of responses to the development of the Product Design Handbook on product testing aspects of attractiveness

\begin{tabular}{llccc}
\hline No & Indicator & Score & Average (\%) & Criteria \\
\hline 1 & $\begin{array}{l}\text { With this, a guidebook increases the interest } \\
\text { in learning Product Design }\end{array}$ & 36 & 72 & Agree \\
2 & $\begin{array}{l}\text { The material presented in the form of a } \\
\text { Guidebook adds motivation to learning }\end{array}$ & 38 & 76 & Agree \\
3 & $\begin{array}{l}\text { With the Guide Book can focus on learning } \\
\text { Product Design }\end{array}$ & 39 & 78 & Agree \\
\hline Average & 75,3 & Agree \\
\hline
\end{tabular}

The results of the analysis by material experts in each aspect of the overall assessment are determined by the scores in each category. The results of the study were analyzed to determine whether or not the development of a Product Design Handbook is feasible. 
Table 8. Results of the average percentage assessment of the development of the Guidebook by media

\begin{tabular}{|c|c|c|c|}
\hline No & Indicator & Average (\%) & Criteria \\
\hline 1 & Aspect of Book Display & 85,6 & Good \\
\hline 2 & Efficiency Aspect & 88 & Good \\
\hline 3 & $\begin{array}{l}\text { Technical Quality Aspects, Effectiveness of the } \\
\text { Guide book }\end{array}$ & 86,3 & Good \\
\hline \multicolumn{2}{|r|}{ Average } & 86,63 & Good \\
\hline
\end{tabular}

Media experts assess the development of the Product Design Guidebook based on three aspects, namely the aspect of book display (85.6\%), efficiency aspects (88\%), and aspects of technical quality, book effectiveness $(86.3 \%)$.

Media experts assess the development of the Product Design Guidebook based on the above three aspects, namely the education aspect (98.0\%), the material accuracy aspect $(96.7 \%)$. The results of the material expert research percentage can be seen in Figure 1 below.

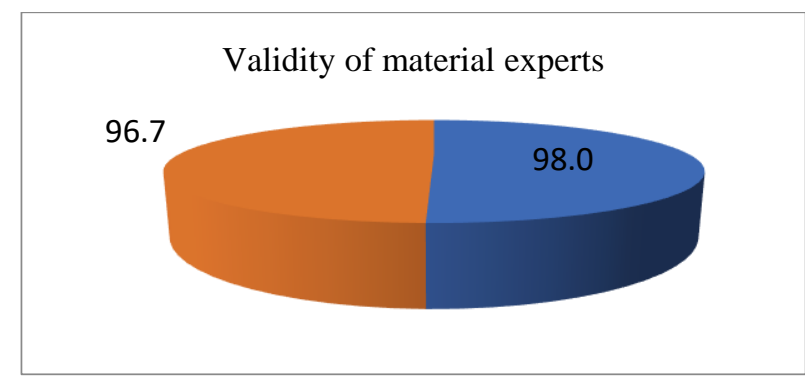

Fig.1. Development of a Guide to Product Design courses by Material Experts.

The results of the analysis of product trial data in each aspect of the overall assessment are determined from the average score in each category. The results of the assessment are then analyzed to determine the shortcomings of the Product Design Handbook. The average results of the percentage assessment of student product trial responses are based on four aspects, namely aspects of attractiveness $(75.3 \%)$, aspects of difficulty $(71 \%)$, aspects of appearance $(74 \%)$, and aspects of benefits $(76 \%)$. Overall in the criteria $(74 \%)$ the percentage of product trials can be seen in Figure 2 below.

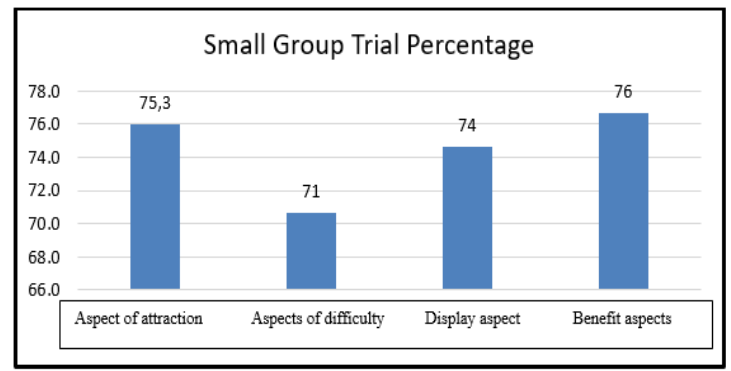

Fig.2. Scoring Guide Book Development Product trial product design. 
The results of the evaluation of the development of the Product Design Guidebook indicate that the products developed are in good criteria and can be continued in use / field trials. The results of the trial data analysis use in each aspect of the overall assessment determined from the average score in each category. The results of the assessment are then analyzed to determine the shortcomings of the Product Design Handbook.

The results of the average evaluation of the trial responses using students while attending Product Design learning are based on four aspects, namely aspects of attractiveness (91.7\%), aspects of difficulty (89\%), aspects of appearance (91.3\%), and aspects of benefits $(91.4 \%)$.

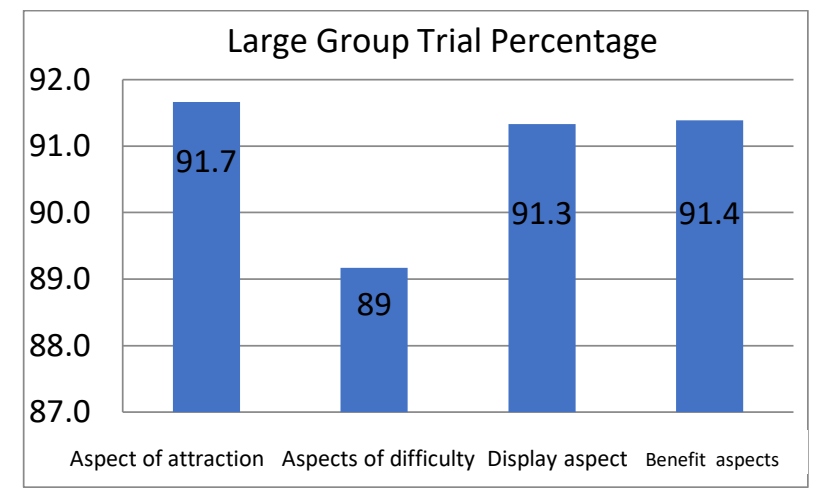

Fig.3. Development of a product trial design manual.

The results of the evaluation of the development of the Product Design Handbook in general, the value of responses from students was considered very Agreeable so that no revisions were made, this can be seen from the product trials and usage trials experiencing an increase in student responses below.

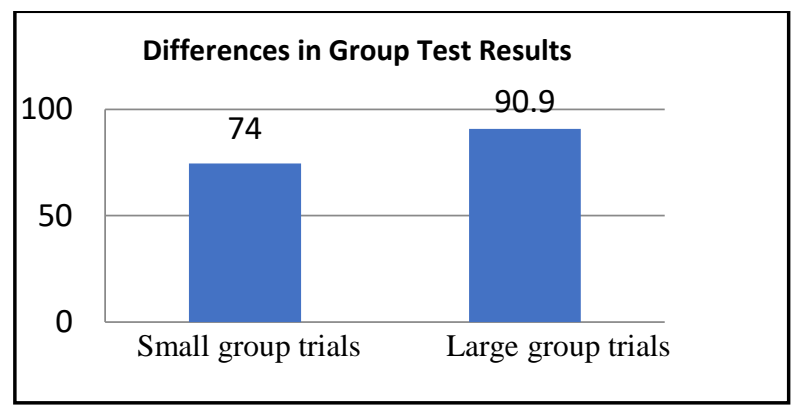

Fig.4. Different bar charts of product trials and usage trials

The results of data analysis on effectiveness tests were conducted to find out which Guidebook products were made feasible or not used as learning media. Effectiveness test is carried out on students who take part in learning Product Design. Analysis of student effectiveness test data. Based on the results of data analysis evaluating media experts, material experts, researchers conducted several revisions to the learning manual product.

Table 9. Comments and Suggestions for Improvement from Material Experts 


\begin{tabular}{|c|c|}
\hline $\begin{array}{l}\text { Material } \\
\text { Expert }\end{array}$ & Comments and Suggestions \\
\hline Material & Pay attention to the groove in the picture in the guidebook \\
\hline Expert I & $\begin{array}{l}\text { Look for images that are easy for students to understand and } \\
\text { interesting }\end{array}$ \\
\hline Material & Already good at preparing Product Design material \\
\hline Expert II & The picture on the guidebook is not complete \\
\hline
\end{tabular}

At the stage of identifying potential and problems, a needs analysis is conducted to Product Design lecturers by giving questionnaires and observations to product Design lecturers to find out about Product Design learning, the curriculum used in Product Design. The development stage then designed the Product Design guidebook. Before the guidebook is complete, the pre-production stage is carried out to draw up an outline of the learning program and the contents of the material through a flow diagram. The development of guidebooks plays a role in determining the title, purpose and points of the learning material. The principle of psychology in making Guidebooks is content organizations [2]. So in the development of the guidebook it is organized and organized in several sequences as outlined in the flowchart, the sequence of presentation of learning material starts from the Standards of competence, basic competencies, indicators, objectives, and material of Product Design.

Based on the results of the data analysis carried out, it was stated that the Product Design Handbook was in a good classification, meaning that it was worth using for the learning guide. The feasibility referred to is the manual book product that has fulfilled the characteristics, namely Self Instructional or independent learning, (Susilana and Riyana, 2009), in fulfilling the Self Intruction character, the indicator guidebook products are as follows: There is competence to clarify the objectives of the learning material given; Presentation of learning material made in stages into activity units, making it easier for students to learn independently; Presentation of Product Design material packaged in books with narratives to support the clarity of presentation of learning material; Product Design Materials given is related to the everyday student environment; Using communicative and simple language so that it is easily understood by all groups.

The field developed in Product Design is closely related to human resources as a key factor in the creative industry, so the aspect that directly needs attention is the learning process. Improvement of development is a change in the learning device. It should also be realized that higher education institutions are one of their visions and missions as agents of change (agents of change), their realization can be measured from the outputs produced, namely the results of creativity and productivity.

Improving the skills of students who are based on local potential, students need to be trained continuously, the main competencies taught are not only skills but more importantly are student soft skills to develop creativity. In accordance with the opinion of Victorino (2004), the general characteristics of local potential are: existing in the environment of a community; the community feels ownership; unite with nature; has a universal nature; practical; easy to understand using common sense; represents inheritance down and down. From the beginning the lecturer entered the class, repeating the learning material, giving apperception in the form of giving motivation to the students to look calm and pay close attention. There are no students who are busy themselves, students have been able to move well in learning. This is in agreement with Bamberger and Tal saying that learning outside the classroom as an effort to create interesting learning and become an alternative choice to avoid boredom and boredom [3]. 
With the preparation of the product design guidebook, it is expected that student creativity in designing skill products by utilizing local potential is achieved well. The development of a Learning Guidebook is directed at adding insight and knowledge about the superiority of regions that have environment. The learning process of Product Design is in the form of attitudes, knowledge, skills and creativity of regional superior products that will be developed by students.

Learning applies an increase in student attitudes, especially in instilling the character and development of the student culture itself. According to Mason (in Timpe, 1992) states that creativity that has sensitivity to problems, is full of original ideas and has flexibility in solving problems. John Baer (2011) states that creativity can train students to be able to solve problems independently.

Indirectly train students to have a brave attitude in facing the new world, train to communicate with others well, develop talents that exist in students, and bring new creative ideas. Opinion of Fasco D. Jr. that education and creativity are closely related, can develop knowledge and learning models to train students to think creatively, the emergence of creativity is influenced by intrinsic factors and extrinsic factors [4]. Seeing the many advantages gained from product design learning from the opinions above concluded that the existence of a learning manual better optimizes student learning resources. The results of this study are in line with the opinion of Horng (2005) arguing that the teaching strategies of creativity abilities that are guided by guidebooks are proven to be successful in increasing student creativity, among others: (1) student-centered learning, (2) use of various learning aids, (3) management good class, (4) linking the content of teaching with real life contexts, (5) using open questions and encouraging students to increase creativity [5].

\section{Conclusion}

The results of the average evaluation of the trial responses using students while attending Product Design learning are based on four aspects, namely aspects of attractiveness (91.7\%), aspects of difficulty (89\%), aspects of appearance (91.3\%), and aspects of benefits (91.4\%). The results of data analysis on the effectiveness test conducted to find out the Guidebook products that are made worthy of being used as learning media. The effectiveness test was carried out on students who participated in Product Design learning for small classes (74\%) and in large group trials $(90.9 \%)$ the effectiveness test data of students. Based on the results of data analysis evaluating media experts, material experts, researchers conducted several revisions to the learning manual products which basically lead to intellectuality, ideas and originality of human resource ideas derived from a combination of thought and creativity in designing, and producing. Advice and infrastructure support as an inseparable part of learning activities requires learning approaches and methods. Thus the creativity of students will not be shackled in a boring routine, even must be fostered and developed to achieve optimal, professional, and have benefits for the wider community including creative industries that can be realized in the Tri Dharma College program.

\section{References}

[1] W. R. Borg and M. D. Gall, Research Education: an Instruction. New York: Longman Tnc, 1983.

[2] A. Arsyad, Media Pembelajaran. Jakarta: Rajagrafindo Persada, 2009. 
[3] Y. Bamberger and T. Tal, "Multiple Outcomes of Class Visits to Natural History Museums: The Students' View,” J. Sci. Educ. Technol., vol. 17, no. 3, pp. 274-284, 2008.

[4] D. J. Fasco, "Education and Creativity," Creat. Res. J., vol. 13, pp. 317-327, 2001.

[5] J. S. Horng, J. C. Hong, L. J. ChanLin, S. H. Chang, and H. C. Chu, "Creative Theachers and Creative Theaching Strategies,” Int. J. Consum. Stud., vol. 29, pp. 352-358, 2005. 